at least one director, there are no mechanisms for appointing even junior staff on a temporary basis; either a public servant, or nothing.

There are recurring problems about research allocations. Laboratory chiefs are usually told, in the February of the year to which the information applies, what their allocation of funds will be. One CNRS director says that last year, after his budget had been cut by 30 per cent with no explanation, it took him until November to get the cut restored. (Luckily, the rules do not require that funds should be fully spent in the year for which they are intended.)

The need to make visits to Paris regularly, either as a member of an advisory committee (which is essential for staying in the swim) or to lobby against some particular injustice, is particularly irksome for those who live and work elsewhere. Reimbursement for the cost of doing so, as for other expenses legitiPLANT SCIENCE mately incurred on CNRS business, is generally agreed to take months. One researcher says that he expects that CNRS will at any stage owe him FF20,000, or a month's salary.

Although many CNRS laboratories on university campuses enjoy the respect of and a good deal of influence with the associated universities, others lead a precarious existence there. One such group has been required to move its laboratory several times in the past seven years to suit the convenience of the university, and is now threatened with another move in October.

The most serious of the complaints against CNRS is that at least some laboratories appear to be inadequately informed of the overall policies that determine their affairs. This seems a shame when the people concerned are every bit as full of enthusiasm for their work as the general run of people working in CNRS laboratories.

\title{
Hungarian sowing seeds
}

ThE Institut des Sciences Vegétales at Gif-sur-Yvette differs from others in the park in that it is brand new and that its director, Adam Kondorosi, is newly arrived, with his wife and co-worker, from Hungary.

The refurbished laboratory is that previously occupied by the teams who danced attendance on Gif's giant phytotrons, which were in the 1960 s proof of CNRS's promise to botanists that they are deserving of large equipment as are nuclear physicists. The phytotrons have now been dismatled and the laboratory disbanded.

Kondorosi has been commuting between Gif and Szeged in Hungary for the past 18 months, while recruiting people for the laboratory. His appearence, more or less permanently, in this Paris suburb justifies earlier fears in Hungary that liberalization would entail the loss of able people (see Nature 344, 611; 12 April 1990).

Kondorosi says that he is enjoying himself enormously, but that whether he will stay for good depends as much on his wife's inclinations as his own. Meanwhile, he says that he has continuing responsibilities at Szeged, mostly for the continuation of his research with graduate students, so that he will have to make occasional visits. CNRS seems compliant.

For the rest, Kondorosi's tale is an illustration of how CNRS (in this case with some help from INRA) sets about founding a new institute. The impetus was the conviction that the molecular and cell biology of plants would have important applications in agriculture. An international committee spent some months head-hunting for a director until it found
Kondorosi (he rattles off the names of those who turned down the job). Now the objective is to recruit a team of people, perhaps internationally, to staff the five research groups whose work will stamp the laboratory's programme (and whose heads are already in place). The hope is to build up to between 60 and 80 people in four years.

One distinctive feature of the programme is that external collaboration is to be built in from the outset. Kondorosi says there are already agreements with the Max-Planck Institute at Köln and the department of molecular biology at Rome, not to mention his old institute in Hungary. He is also planning to work closely with the complementary CNRS institute at Toulouse, and is hoping for further support from the European Communities and from the European Molecular Biology Organization.

Kondorosi's own field is the study of how the symbiosis of rhizobia and plant roots is reflected in and mediated by the reciprocal exchange of chemical signals between them, which is one leg of the institute's programme. Another group will aim at similar understanding by more classical studies of the hairy-root syndrome (a variant of crown gall disease). There are also groups concerned with plant cell signalling (by means of auxin), the mechanism of damage by plant viruses and the molecular genetics of Arabidopsis - the eukaryotic plant with the smallest genome so far recognized.

Like other up-and-coming CNRS laboratories, the new plant sciences institute is already embarking on graduate education. Five or six students seeking the

\section{Regional consuls in the wings}

MME Katherine Piquet-Gauthier is the new regional delegate of CNRS at Montpellier, with responsibility for CNRS affairs in Languedoc-Rousillon in the south-west of France. She is one of a dozen people appointed last May, under the terms of a decree promulgated by CNRS last December, to offer regional groupings of laboratories with a more immediate presence than Paris can provide. But it is not yet clear how far administrative devolution will go.

The twelve regions and the sites of CNRS's regional offices are Alsace (Strasbourg), Aquitaine and Poitou-Charentes (Bordoaux), Brittany and Loire (Rennes), Limousin (Orleans), Ile de France (see below), Langeudoc-Roussillon (Montpellier), Lorraine-Ardennes (Nancy), MidiPyranees (Toulouse), Normandy (Caen), Provence-Côte d'Azur (Marseille) and Rhône-Alpes (Lyon). The administrative centre for the Pas de Calais region had not last month been chosen.

Many of the regional directors have not yet taken up their posts. The arrangements for the Ile de France (greater Paris) are complicated by the great concentration of CNRS responsibilities in the region, with the result that there will be five subregional directors working through a central office. Similarly, there will be two sub-offices in the Rhône-Alpes region catering separately for Lyon and Grenoble.

What will the regional offices and their directors be able to accomplish? Laboratory directors and researchers have a variety of aspirations for the new arrangements. Those who labour under a sense of neglect hope the new arrangements will give them a stronger voice in Paris. More immediately, there is also the prospect that the regional offices will simplify the bureaucratic structure (although some fear that their influence may be in the other direction).

On the question of whether devolution will make it easier to pay people's legitimate travelling expenses more quickly, Mme Piquet-Gauthier says "not yet, but wait and see whyat it's like when you're here next".

DEA diploma (a pre-PhD qualification see page 122) have already been accepted for next year. Kondorosi expects that university relations will be simplified because two of his group leaders are also university professors.

But will there be enough teachers for them? Kondorosi says he has already advertised 18 vacant positions at the institute. There can hardly be a quicker way for someone from Eastern Europe to learn the ways of the competitive West than he has chosen. 